\title{
Textual Enhancement-Based Grammar Instructional Design for English Students
}

\author{
Veni Roza \\ English Education Department \\ IAIN Bukittinggi \\ Bukitinggi, Indonesia \\ veniroz_501@yahoo.com \\ Hermawati Syarif
English Department
UNP
Padang, Indonesia
}

\author{
Desmawati Radjab \\ English Department \\ UNP \\ Padang, Indonesia
}

\author{
M. Zaim \\ English Department \\ UNP \\ Padang, Indonesia
}

\begin{abstract}
The article was derived from an author's dissertation which was supervised by three promoters. Theresearch was designed to answer students' need in the field that they need current grammar teaching model which demands students to get involved actively in the learning process by noticing and discovering grammar rules in the context by their own. This paradigm goes with the student-centered approach where lecturer acts out as facilitator while students' role is more dominant than teachers'. To achieve this goal, the researcherapplied Research and Development (R\&D)by Thiagarajan et al (1974)'s Four-D Model; defining, designing, developing, and disseminatingstages. This paper focuses on designing stage to design the grammar instructional model which is called textual enhancement-based grammar instruction model or TEBGIM. The research finding exhibits that conceptual model of TEBGIM is assumed to be effective for grammar teaching.
\end{abstract}

Keywords--Textual Enhancement-Based Model Design; Grammar Instruction

\section{INTRODUCTION}

Many experts said that grammar is prominent element in language teaching. Teachers as practioners perceive the same. This positive perception should picture out the implementation of grammar teaching in the classroom by means of teachers' preparation, teaching material, media, method of teaching and so forth. Based on fact, mostly grammar teachers only relied on their teaching preparation on what they have in their mind and delivered it to students with higher proportion of teacher-talking time. Another salient phenomenon was that grammar teaching material was taken from decontextualized grammar book. This condition makes grammar as essential element fail to support students' successfulnessin Englishperformance.

To overcome this problem, the researcher needs to conduct a research and development to answer students' need in the fields. Based on the results of defining stage that researcher found that skills and subskilss needed by students for grammar learning were reading, writing and vocabulary. The most important topic for students to learn was complex sentences. Selection of appropriate model was the one which stresses student-centered with focus on form (an approach with optimal conditions for learning by drawing students' attention to linguistic forms in the context of meaningful communication, [1] by discovering rules by their own which is not dominated lecturers' talk. Selection of instructional material which fulfiled students' need wa very crucial to carry out since lecturers only used limited learning resources taken from decontextualized book. There was no need to adopt nor adapt the grammar book used so far, so it was essential for lecturer to design and develop grammar material based on students' need [2], so that the researcher needs to design TEBGIM.

\section{REVIEW OF RELATED THEORIES}

\section{TEBGIM and Information Processing Teaching Model}

Teaching model is a model of a plan or pattern that can be used to shape curricula, to design instructional materials and to guide instruction in the classroom and other settings. [3]. In line with that, it is a conceptual framework which describes systematic procedure and organizes learning experiences to achieve the objectives pre-determined [4]. Teaching model is designed for specific purpose, which depends on the teaching of information concepts, ways of thinking, the study of social values and so forth. In designing the model, students are expected to engage in particular cognitive and social tasks. The models of teaching are evidently varied. Some models center on instructor delivery while others are developed as the learners respond to tasks given. Regardless of the various teaching models, models emphasize how to help students learn to construct knowledgelearning how to learn.

Information Processing Models which base TEBGIM focus on intellectual capacity. They are concerned with the ability of the learner to observe, organize data, understand information, form concepts, employ verbal and nonverbal symbols and solve problems. The primary purposes of this model are the mastery of methods of inquiry, the mastery of 
academic concepts and facts and the development of general intellectual skills such as the ability to reason and think more logically. Models that belong to this family are the concept attainment model, taba inductive thinking model, inquiry training model, the advance organizer model, the memory model, cognitive growth model and biological science inquiry model.

There are five important structures constructing models of teaching, they are; Syntax, Social System, Support System, principle of reaction and Effect of the Model [3]. Syntax is phases or steps of the model which describes the model in action. It is the systematic sequence of the activities in the model and each model has a distinct flow or phases. The Social System describes the role and the relationship between the teacher and the students. In some models, the teacher has a dominant role, other models, however the activity is centered on the students or the activity is equally distributed. Principle of Reaction informs the teacher how to consider the students and how to respond to what the students do. It provides the teacher with rules to select models and appropriate responses to what the students do. Support System describes the supporting condition required to implement the model. Support in this case is additional requirements other than the usual human skills, capacities and technical facilities. Effect of the model results in two types, the intsructional and the nurturant effect. The instructional effect are direct effects of the model which results from the content and skills on which the activities are based while the nurturanteffects are effects that are implicit in the learning environment and they are indirect effects of the model.

\section{B. Theories that Support TEBGIM}

\section{Constructivismas Philosophical Base}

Constructivism is as philosophical base of TEBGIM. As its name suggests, constructivism sees learning as a process of constructing or making something. Constructivism says that students learn by making sense out of the world; they make meaning out of what they encounter. It can be defined as meaning making rooted in the context of the situation whereby individuals construct their knowledge of and give meaning to the external world (context).

The basic precepts of learning according this philosophy are an active process of meaning-making gained in and through our experience and interactions with the context. Learning opportunities arise as students encounter cognitive conflict, challenge, or puzzlement and through naturally occurring as well as planned problem-solving activities. Learning is a social activity involving collaboration, negotiation, and participation in authentic practices of communities. Students should take primary responsibility for their learning and own the process as far as possible. These ideas reflect the nature of constructivist theorizing and of course TEBGIM itself.

\section{Cognitive as Psychological Base}

Cognitive or information processing is mentioned as psychological base of TEBGIM. Information processing theory regards the environment as playing an important role in learning. Three sensory memory in the learner sensory, short term and long term memory are assumed to receive information from the environment and transform it for storage and use in memory and performance. With sensory memory, learners perceived organized patterns in the environment and begin the process of recognizing and coding of these patterns. Short term memory permits the learner to hold information briefly in mind to make further sense of it and to connect it with other information that is already in long term memory. Finally long term memory enables learners to remember and apply information long after it was learned. Above all, attention, encoding and retrieval are important. In short, TEBGIM goes with cognitivist how people transform, elaborate, store and recover information.

Moreover, in cognitivist view, active learners are people who initiate experiences, seek out information, and reorganize what they already know to achieve new insights, pursue goals, solve personally relevant problems, and attempt to make sense of the world [5]. Various automatic mental control processes, schemata, and other mental mechanism help the brain to deal with both familiar and unfamiliar situations.

\section{Second Language Acquisition}

TEBGIM is one of the input-based approaches. The notion of input has become a recurrent theme in the field of both foreign language teaching and second language acquisition for the past few decades. The importance of input in acquiring language both first and second language is undisputable. As defined by Van Patten in Nassaji \& Fotos, input is what the learners hear or see to which they attend for its message [1]. Therefore, it has an essential role in second language acquisition since it is the sample of language that the learners are exposed to and attempt to process for meaning.

As the input is the source of language acquisition, acquiring second language is commenced with the input the learners are exposed to. In relation to the input in the second language learning, the learners will face two kinds of input in the process of acquiring the target language [6]. The first input is known as interactional input. This input refers to the target forms the learners receive through communicating. The second one is known as non-interactional input. Unlike interactional input, the non-interactional input is received through non-communicative way such as from reading a text or listening to a talk show etc.

However, all language inputs the students receive are not equally necessary to acquisition as some of them will be left unprocessed. The input is potentially processible language data which are made available to the language learners while intake refers to what actually processed in the learners' mind for acquisition [7]. This notion suggests that some language input might be unnecessary for students as they won't probably be applied for further acquisition process. In addition to these proposed theoretical bases of intake, as the part of the 
input that the learners have noticed and have stored in their working memory for further processing [1].

Given the importance of intake, it is important to transfer input into intake. In order to transfer input into intake, noticing should be involved. In the relation of intake and noticing, intake is that part of input that the learner notices. In other words, to make use of input in language acquisition, the learners are required to notice it as it is the way to transfer into intake [8]. In his work, noticing input requires focal attention and awareness on the part of learners [9]. From this standpoint, it can be inferred that the learners' attention is needed to be drawn to the target input. In line with this view, [1] mention that noticing refers to the conscious registration of language forms, presented in input, into learner mind. This notion suggests that noticing process involves consciousness storing of language input.

\section{METHOD}

The researcher applied Research and Development by undertaking Four-D model of defining, designing, developing and disseminating stages. For this researcher, she focused on designing stage by referring to the result of defining stage and theoretical reviews. The instruments used were document and result analysis of needs in defining stage. The results of defining stage are depicted by Table 1

Table 1 The Relationship between the Defining and TEBGIM Design

\begin{tabular}{|c|c|c|c|c|}
\hline \multicolumn{2}{|c|}{ Defining stage } & \multirow{4}{*}{$\begin{array}{l}\mathbf{D} \\
\mathbf{I} \\
\mathbf{S} \\
\mathbf{C} \\
\mathbf{R} \\
\mathbf{E} \\
\mathbf{P} \\
\mathbf{A} \\
\mathbf{N} \\
\mathbf{C} \\
\mathbf{I} \\
\mathbf{E} \\
\mathbf{S}\end{array}$} & \multicolumn{2}{|l|}{$\begin{array}{l}\text { Designing } \\
\text { TEBGIM }\end{array}$} \\
\hline Lecturer & $\begin{array}{l}\text { Dominated by } \\
\text { lecturers' talk. } \\
\text { Lecturer- } \\
\text { centered with } \\
\text { traditional } \\
\text { model of PPP } \\
\text { (Focus } \\
\text { onFormS) }\end{array}$ & & Lecturer & $\begin{array}{l}\text { Facilitator, } \\
\text { Motivator, } \\
\text { Lesson Guide, } \\
\text { Talk-Less with } \\
\text { current model of } \\
\text { Input } \\
\text { Enhancement } \\
\text { (Focus on Form) }\end{array}$ \\
\hline Students & $\begin{array}{l}\text { Passive } \\
\text { receiver, } \\
\text { Listening to } \\
\text { lecture. }\end{array}$ & & Students & $\begin{array}{l}\text { Active thinker, } \\
\text { Getting involved, } \\
\text { Solving } \\
\text { problems, } \\
\text { Discovering } \\
\text { rules. }\end{array}$ \\
\hline Materials & $\begin{array}{l}\text { Discreet } \\
\text { grammar } \\
\text { features } \\
\text { Limited } \\
\text { learning } \\
\text { resources, } \\
\text { Sentence } \\
\text { level, } \\
\text { Rote learning. }\end{array}$ & & Materials & $\begin{array}{l}\text { Integrated with } \\
\text { reading, writing } \\
\text { and vocabulary } \\
\text { building. } \\
\text { Wider resources, } \\
\text { Full of context, } \\
\text { Meaningful, } \\
\text { Religion texts. }\end{array}$ \\
\hline
\end{tabular}

Based on Table 1, the researcher found some problems related to grammar lecturers who still teach by using traditional model by explaining the lessons since beginning to introduce new lessons. The class was dominated by lecturer's talk then. Students became passive leaners who receive information from their lecturers. They did not get involved in the process of learning and it becomes rote learning. The materials used in teaching were taken from a book which is also presented in PPP model with lack of context or in discreet way. The tasks presented for students did not make them able to transfer declarative knowledge of grammar into procedural knowledge of how to use that knowledge in actual communication. Based on these discrepancies, the researcher proposes a model of grammar instruction which emphasizes on students' need.

\section{FINDING AND DISCUSSION}

To begin data analysis, the researcher presented the following figure on how TEBGIM works based on the analysis results at defining stage and theories review. The model was based on constructivism philosophy (Wilson, 2012) where students actively get involved in the learning process to construct their knowledge of grammar since what student does that he learns [10], not what the teacher does. It is also with the quotation "Teachers can give students ladders that lead to higher understanding, yet the students themselves must climb these ladders". It is then becoming base for student-dominated learning or student-centered.

Moreover, the model also goes with information processing teaching model by [3] and cognitive learning theory which stresses intellectual capacity of students. Importantly, the prototype model was originated by [9] who proposed consciousness-raising for the first, and then he changed it to input-enhancement. [9] work for input enhancement of language meanwhile Nassaji and Fotos (2014) with textual enhancement that the researcher referred when designing TEBGIM. Moreover, she applied textual enhancement by referring [6] with sequence of grammar instruction to present enhancement of the text as the syntax of TEBGIM. The result of this master piece was called conceptual model which is presented in Figure 1: 
Figure 1 Conceptual Model of TEBGIM

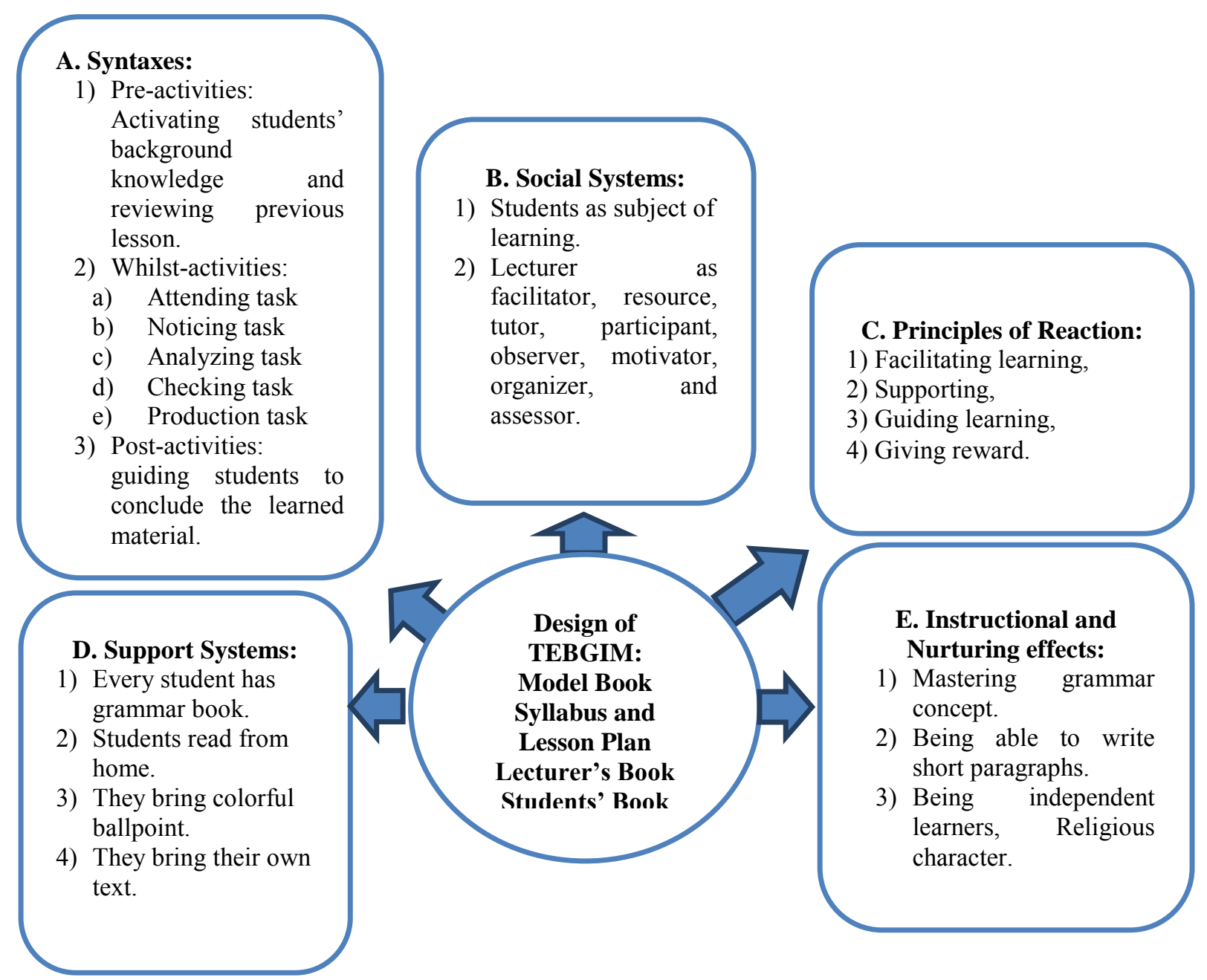

Based on Figure 4.1, there are five components of model when implementing a certain model including TEBGIM. The first is syntax. There are three activities here pre, whilst and post activities. In pre activities, lecturer activates students' background knowledge by showing pictures. In whilst-activities, five activities are accomplished by students; they are: attending task demands students to attend both for form and meaning of texts; noticing task lets them to be able to find and mention the patterns of grammar features enhanced in the text; analyzing task asks students to read and analyze unenhanced texts; and production task gets students to construct their sentences and paragraphs employing certain grammar features. In post activities, lecturer guides students to conclude lessons. The second is social systems. Students act as subject of learning meanwhile lecturers are as facilitator, guide of students and motivator. The third is principles of reaction where are certain rules understood by lecturers and students. They are: lecturers make sure that students understand the grammar lesson with TEBGIM and facilitate them; Lecturers support them to learn by providing any material needed for learning; lecturers guide students how to study under TEBGIM, They give feedback and reward to students. For students, they need to read grammar books before coming to the class in order to help them in the classroom so, they need to own them. The forth is support systems which include conditions supporting the grammar learning under TEBGIM like students have their own grammar books, these books need to read before coming to the classroom, they bring colorful pens to indicate grammar features found in the text. The fifth is instructional effects of the model that students' grammar mastery in complex sentences is improved and that 
students are aware the importance of grammar in language learning, independent learners, and have religious characters eventually are the nurturing effects. Here is elaboration of each in more detail:

\section{A. Syntax}

Syntax of TEBGIM consisted of three namely preparation, implementing and evaluating stages. Like other models, TEBGIM began with preparation of lecturer before implementing it in the classroom. To prepare it, it was crucial for lecturer to consider some aspects so that TEBGIM produced was effective and not flood of input. Here is the step:

\section{Preparation}

In this stage, the researcher designed the enhanced text by presenting the salient part of language input (English complex sentences) in grammar instruction to draw students' attention to notice it by using various typographic devices; bolding, underlining, and italicizing, and coloring grammar features which would be taught.

When designing the TEBGIM, the researcher considered some aspects, they are:

a. Creating a particular point the students need to notice of,

b. Highlighting that feature in the text,

c. Not highlighting many different forms as it will distract learners' attention,

d. Using strategies to keep learners' attention from meaning,

e. Not providing any additional metalinguistic explanation.

\section{Implementing}

To implement TEBGIM, there were three phases, pre, whilst and post activities accomplished by lecturers and students. In pre-activities, students' readiness to learn was very crucial here. The readiness was shown in willingness physically and mentally. Students did not talk with their friends anymore, and they paid attention to what lecturer said. In whilst-activities, students executed what they were supposed to doing and lecturer acted out as facilitator and motivator. At post, they summarized the material which was learned. Here is elaboration each of them:

\section{a. Pre-Activities}

A lecturer activated students' background knowledge by showing pictures related to materials. For instance, they would learn grammar feature of simple sentence in the text about nature of religion; so the lecturer showed a picture of religion symbol to see students' recognition of certain religion. It was prominent for lecturer to do it in order to draw students' attention before coming to lesson. Sometimes, they were not ready yet and still busy with their smartphones even though the lecturer called the roll and got them to pray. The lecturer needed to engage them with the topic to learn.

\section{b. Whilst-Activities}

In whilst-activity, there were five tasks which were carried by students and facilitated by the lecturer. In this model, students discovered how grammar works on their own so that such tasks made the students much less dependent on the lecturer. These were tasks that provide students with "data" about how a particular grammatical structure work and help them work out the rule for themselves:

1) Attending task was a step where students read to a text carefully that they process for meaning. Students paid attention to the text to attend to its meaning in order to help them answer some questions related to the text. Meanwhile, the lecturer acted out as facilitator to have students read the text which was already provided for them.

2) Noticing task was a step where students reread the same text but they paid attention to the grammar features. Meanwhile, the lecturer acted as motivator to get students to notice on the grammar features inside the text. If students could not notice them, she guided students to notice the italic sentences, the bold or the colored ones inside the text.

3) Analyzing task was a step where students were asked to discover how the target grammar structure works by analyzing the new text by reading it carefully. Meanwhile, the lecturer acted as facilitator and got students to analyze the text and to enhance grammar features found inside the text by their colorful ballpoints.

4) Checking task was a step where students completed an activity to check if they understood how the target structure works. The lecturer helped students check if they understood how the target structure works by actions of identifying, classifying, combining or reducing sentences to form complex sentences.

5) Production task was a step where students were given the opportunity to try out the target structure in their own sentences or short paragraphs. The aim of the production task was to encourage students to experiment with the target structure. It was a goal that was more compatible with the current emphasis on communication and students' autonomy.

\section{c. Post-Activities}

This phase did not mean that the lecturer closed the lesson and said goodbye to students. In post activities, the lecturer guided the students to conclude the learned materials. It was undertaken by students to see their comprehension on grammar lesson.

\section{Evaluating}

The lecturer examined students' intake and output on grammar features after treated under TEBGIM. The 
lecturer gave them formative test at the end of each lesson, by providing the students with the task by reading another text related to learned topic at home and enhancing certain grammar features within the text by underlining or coloring them. She also got students to create their own texts by employing particular grammar features.

\section{B. Social System}

Based on Academic Guide book OF IAIN Bukittinggi, there are at least fourteen meetings for each subject in a semester including midterm and final test. For this model, the model was carried out for thirteen meetings with thirteen topics of grammar lessons. Other three meetings were for pretest, midterm and posttest sessions.

Moreover, the social system between lecturer and the students under TEBGIM was overt. Lecturer and students participated in grammar classes actively. Lecturer acted out mainly as facilitator and students as executors. At the beginning of grammar lesson, the lecturer activated students' background knowledge by showing pictures related to grammar topic. Then, she facilitated students to read enhanced texts. Next, they discus some questions related to the text with their pair. Here lecturer might act out as tutor if students got problems to understand texts. After doing this task, students reread the text and noticed the highlighted features in the text by processing this input in their mind. If students could not notice them, she offer help as resource that students pay attention to the enhanced features. Having got the answer, they share with the class what they can learn from it, the pattern or formula in analyzing task. At checking and production tasks, lecture acted as assessor to see if students understood the grammar points or not through their writing production.

\section{Principle of Reaction}

In line with theories of focus on form approach (FonF), textual enhancement of input, inductive way of grammar teaching, the role of lecturers in the TEBGIM was as a facilitator for students. The lecturer helped students and had them learn the grammar through reading, noticing and discovering rules of language in texts by themselves. They only guided students to pay attention to particular grammar features which were already enhanced and notice them. If they did not notice the intended ones, the lecturer guided them to notice the colored or highlighted features. After that, students process for both the form and the meaning and discuss the answers with their pair. Since beginning of the lesson, students' role was dominating the learning process because their lecturer only helped them for guide to carry out tasks which should be fulfilled. The lecturers also gave reward to students in learning process. In short, principles of reaction of TEBGIM lecturer had role in facilitating learning, supporting students, guiding the students and giving reward.

\section{Support System}

Support system was circumstances that supported TEBGIM to take place magnificently. The conditions were (a) students had learning resources with them, in this case grammar book designed under TEBGIM purposed for students. It means everybody possessed a grammar book with her. (b) Students had to read materials provided for them before coming to the classroom. They could study well and become passive receiver when they were empty attending the grammar class. (c) They needed to bring colorful pen to mark the intended grammar feature found inside the text.

Moreover, support system of this model referred to additional requirements which include grammar books suggested like Mosaic Grammar by Werner, Just Grammar by Harmer, and others to add students' reading on certain grammar topic; and also facility like projector was also needed to help lecturer show the activities accomplished by students.

\section{E. Instructional and Nurturing Effects}

Instructional effects of TEBGIM were to make students able to master the concepts of complex sentences as the cognitive aspect, and able to apply them in the production that was in writing skill as the psychomotor aspect. Instructional effects of TEBGIM were obtained by students after they learnt the concepts of complex sentences through TEBGIM for thirteen meetings. After they were educated through reading, noticing, processing to discover the grammar features in the enhanced texts by their own, it aided them in production to correctly write paragraphs skillfully applying complex sentences eventually.

In the meantime, the nurturing effects of TEBGIM were to make students more spiritual due to the Islamic theme of texts, more autonomous as they developed their analytical ability in analyzing texts by their own and raising their awareness of the importance of grammar features in language and to train inductive and logical thinking.

\section{CONCLUSION AND RECOMMENDATION \\ The researcher proposed TEBGIM which is} believed to answer need analysis in defining stage which challenges students to analyze texts and requires students' active involvement with meaningful context of grammar material. Based on the tasks that have been designed by the researcher in TEBGIM syntax, four out five tasks belong to input processing in students' mind. Only production is form of output. It means this model relies on students' processing in their cognitive first until they understand. The social system between lecturer and the students under TEBGIM was overt. In the beginning until the end of grammar lesson, students had dominant role to play since this model was characterized by its students-centered. During the grammar lesson using TEBGIM, lecturer acted out as facilitator; she facilitated students to do each step under TEBGIM to read an enhanced text, to notice the text, to analyze an unenhanced text, to check the pattern and to produce their 
own paragraphs. Moreover, the principle of reaction of TEBGIM told how the lecturer regarded the students and responded to what the students did. Lecturer guided students whenever they failed doing the task. Furthermore, support systems that supported TEBGIM were (a) students had learning resources with them (b) Students had to read materials provided for them before coming to the classroom. (c) They needed to bring colorful pen to mark the intended grammar feature found inside the text.The last is instructional effects of TEBGIM were to make students able to master the concepts of grammar features taught and make students more spiritual due to the Islamic theme of texts used.

\section{References}

[1] Nassaji, Hossein and Sandra Fotos. Teaching Grammar in Second Language Classrroms Integrating FormFocused Instruction in Communicative Context. Routledge: New York and London. 2011

[2] Roza, Veni. Developing Textual-Enhancement-Based Grammar Instruction Model. Elixir International Journal. Volume 2, Issue 3. 2017

[3] Joyce, Bruce \& Marsha Weil. Models of Teaching.Eighth Edition. USA: Allyn and Bacon A Simon \& Schuster Company. 2009

[4]Sugiyono. Metode Penelitian Pendidikan (Pendekatan Kuantitatif, Kualitatifdan R\&D).Edisi Revisike Tujuh Belas. Bandung: Alfabeta. 2013

[5] Diaz-Rico, L.T. Strategies for Teaching English Learners. New York: Pearson Education, Inc. 2008

[6] Ellis, R. \&Gaies, S. Impact Grammar. Hong Kong: Addison-Wesley Longman. 1997

[7] Sharwood Smith, $M$ and John Truscott. Explaining Input Enhancement: a MOGUL Perspective. De GruyerMountonIral, p. 253-281. 2014

[8] Schmidt, R. Attention in P. Robinson (Ed.) Cognition and Second Language Instruction. (pp.3-32). Cambridge University Press. 2001

[9] Sharwood Smith, M. Input Enhancement in Instructed SLA.Cambridge University Press.SSLA,15, 165-169. 1993

[10]Ansyar, Muhammad. Kurikulum: Hakikat,Fondasi, Desain \& Pengembangan. Jakarta: Kencana Prenada Group. 2015 